
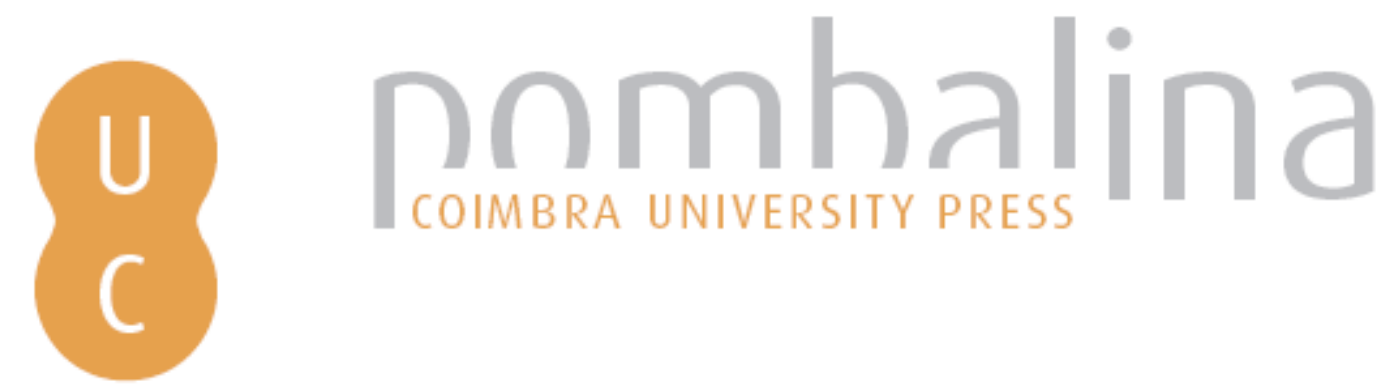

\title{
Hypatia and the Idiosyncrasies of Christianity in Egypt: a study of the events occurred at Easter 415 A.D. in Alexandria
}
Autor(es):
Dias, Paula Barata
Edições Afrontamento; CITCEM - Centro de Investigação Clássicos e Humanísticos; Alexandria University; Imprensa da Universidade de Coimbra
Publicado por: Transdisciplinar «Cultura, Espaço e Memória»; Centro de Estudos

URL persistente:

URI:http://hdl.handle.net/10316.2/36187

DOI:

DOI:http://dx.doi.org/10.14195/978-989-26-0966-9_21

Accessed : $\quad$ 26-Apr-2023 12:28:04

A navegação consulta e descarregamento dos títulos inseridos nas Bibliotecas Digitais UC Digitalis, UC Pombalina e UC Impactum, pressupõem a aceitação plena e sem reservas dos Termos e Condições de Uso destas Bibliotecas Digitais, disponíveis em https://digitalis.uc.pt/pt-pt/termos.

Conforme exposto nos referidos Termos e Condições de Uso, o descarregamento de títulos de acesso restrito requer uma licença válida de autorização devendo o utilizador aceder ao(s) documento(s) a partir de um endereço de IP da instituição detentora da supramencionada licença.

Ao utilizador é apenas permitido o descarregamento para uso pessoal, pelo que o emprego do(s) título(s) descarregado(s) para outro fim, designadamente comercial, carece de autorização do respetivo autor ou editor da obra.

Na medida em que todas as obras da UC Digitalis se encontram protegidas pelo Código do Direito de Autor e Direitos Conexos e demais legislação aplicável, toda a cópia, parcial ou total, deste documento, nos casos em que é legalmente admitida, deverá conter ou fazer-se acompanhar por este aviso.

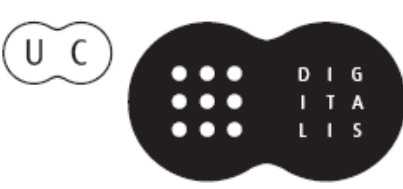




\title{
HYPATIA AND THE IDIOSCYNCRASIES OF CHRISTIANITY IN EGYPT - A STUDY OF THE EVENTS OCCURRED AT EASTER 415 A.D. IN ALEXANDRIA
}

\section{PAULA BARATA DIAS}

University of Coimbra. Centro de Estudos Clássicos e Humanísticos (University of Coimbra).

\begin{abstract}
When compared with other regions of Roman Empire, Egypt was early and intensively converted into Christianity. In Egypt, Christianity was almost a phenomenon of masses, characterized also by a well distinguished militancy, spirit of martyrdom, and popular adhesion. These particularities can be explained by the social, political and religious background. It is our aim, in this paper, to look closer into the context and events which conducted to the Hypatia's Death, to follow the political response regarding street violence in Alexandria. Far for holding attenuate circumstances to dramatic events, the analysis of literary testimonies and legal documents will frame the Hypatia's death episode in the major conflictive context of social and religious tensions in Late Egypt.
\end{abstract}

Since the establishment of the early Christian communities, Egypt has played a prominent role amongst the regions of the Roman Empire in which Christianity was defined by greater popular expression, military display and belligerence. In fact it was in Egypt that Christianity first emerged as a religion on a wide scale, embraced by the masses, a phenomenon in itself greatly determined by the social, political and religious particularities of that region which has welcomed the new religion.

Hypatia of Alexandria was a prominent figure in the classical world. As such this chapter not only takes into account the events surrounding the tragic death of the philosopher but at the same time, through the examination of documents and surviving testimonies, it 
attempts to evaluate if the answer for such tragic ending can be found in the special characteristics that defined the city of Alexandria in those days. We do not endeavor to search for lawful reasons that led to her appalling murder through lynching, a form of death which sadly has so often been cited throughout the history of mankind. However the consideration given to the precedents and the motivations behind Hypatia's death and the attempt to scrutinize them, as incomprehensible and unforgiving any act of violence practiced against the defenseless may be, such consideration however might shed another light on what was effectively in question, thus helping voice the truth owed in defense of the victims caught out in this episode.

Born in 370 A.D., Hypatia belongs to the group of distinguished figures of Antiquity whose popularity precedes more from the tragic ending of their lives, in this case in her native Alexandria in the year of 415, than from their lives, in this case a short one dedicated to the diffusion of knowledge, mathematics, astronomy and philosophy. It is rather unfair that the emphasis put on the dramatic events leading up to Hypatia's death has overshadowed, to its detriment, her achievements in life particularly in the field of philosophy.

In this way Hypatia's victimization is double edged: on one hand she has been catalogued and reduced to the status of a martyr in an era of decaying paganism, by being sacrificed to the intolerance of a domineering Christianity, and on the other, she remains a prisoner and an adequate symbol of the ideological conceptions of those who have written about her, despite their admiration for her. This ideology was the dominant posture adopted about Hypatia during the age of Iluminism. Literature, in particular the one diffused during the period of Romanticism, has greatly contributed towards defining Hypatia's image as the heroin of martyrdom, victim of male greed ${ }^{1}$. Scientists and contemporary divulgers alike, uphold her as a symbol of free science's fragility, in a world enslaved by ideologies ${ }^{2}$. Eventually only after the Sixties would Hypatia become the bastion of several feminist movements ${ }^{3}$.

\footnotetext{
${ }^{1}$ Diodata Saluzzo Roero's (1827), in her Ipazia ovvero delle Filosofie wrote that Hypatia converted to Christianity through Cyril's influence and that her death was the result of her denial to give in to the romantic advances of the patriarch. The French poet Leconte de Lisle, in two of his works, named Hypatie (1847) and Hypatie et Cyrille (1857) tells the story of a damsel of vulnerable authenticity and beauty. Charles Kingsley (1873), Hypatia of Alexandria, historical novel of the English romanticism.

${ }^{2}$ In the twentieth century, Bertrand Russel reemphasized the purpose of her death, uplifting her status to that of symbol of subservience of science to the established social rule: «This way, in the year of 414 A.D. the status of philosopy in the intellectual metropolis of the world was sealed; from then on science will have to endeavour an obscure and subordinate status. Its public display will no longer be tolerated...» (B. Russel, Hystory of Western Philosophy and Its Connection with Political and Social Circumstances from Earliest Times to the Present Day, London, 1946, p. 387.; also the scientist and writer Carl Sagan, in its well known book Cosmos). Further information is available on the internet through his documentary about the city of Alexandria, whose scientific venture culminated with Hypatia's death (episode 13 of the series Cosmos, mn. 32-35 $<$ http://www.youtube.com/watch?v=1zuD-JbAXYI>).

${ }^{3}$ Hypatia: A Journal of Feminist Philosophy. Center for Humanities: University of Washington.
} 
In fact, in ancient literary sources, the narrative of the death of this singular figure of Antiquity, corresponds to the nucleus of documented conventional information and to some extent the only one to bear factual credibility. Any other personal aspect of hers has been portrayed in a divergent and controversial way: her biography, the nature of her studies, her religious identity and finally the social settings that enveloped her existence. There is no unanimous opinion either with regards to those responsible for the tragic events associated with her death, or even its motivation, in the sense that the narratives concerning Hypatia's death offer more information about their author than the subject in question.

The truth about the real Hypatia has been further veiled by the fact that no work or literary fragment directly attributed to her was ever found or has survived to this day, casting her into that silence that throughout history has been the fate of all the women who dared to take on a role otherwise solely reserved to the male gender. Despite all the studies conducted in the fields of science and history, in order to prove Hypatia's contribution in the areas of mathematics, geometry and astronomy, these have become mere probabilities since they have been painstakingly collected from indirect sources.

The Italian Renaissance artist, Raphael, has included her amongst the philosophers and illustrious figures in his frescoed masterpiece The school of Athens, surrounding her with eminent philosophers such as Pythagoras, Parmenides, Heraclitus, Zeno of Elea, Epicurus, Averroes, all of which have their eyes turned to books or documents, or simply aiming their inquisitive and unreserved minds at one of the figures in the painting. Hypatia is the only figure, in this composition, without any book or document where to fix her eyes onto. Of significant importance is also the fact that she is the only figure, in the whole painting, whose eyes are fixated on the observer, and such look arouses in us a double question: on one hand who were effectively her intellectual counterparts in the classical world, which authors did she read and who read the works she wrote? On the other hand, what more can the actual receiver of the figure of Hypatia know beyond the tragic circumstances of her death?

Let us look in brief at her most prominent facets, that of scientist and philosopher and in particular that of mathematician: Hypatia was the daughter of Theon of Alexandria, and as her father's disciple and assistant, she would helped him and gain an insight on the commentaries he dedicated to Euclid's works including his Elements, Data and Optics. Gathered through the Byzantine tradition, we owe it to Theon of Alexandria great part of what is known today not only of Euclid's work but also of Ptolemy's Handy Tables and Almagest ${ }^{4}$; The Suda identifies him as a scholar and member of Alexandria's Museum, one who held great interest in astronomy and who was also capable to predict the eclipses of the sun and the moon from observations conducted in Alexandria. Following on her father's footsteps, Hypatia devoted her life to the study and commentaries of the Alexandrian mathematicians

\footnotetext{
${ }^{4}$ Oxford Dictionnay of Byzantium, 1991; ZIEGLER, 1934: 2078-2079; DZIELSKA, 2009: 84-94.
} 
such as Apollonius of Perga (3rd century B.C.), author of Conic Sections; and Diophantus (3rd century A.D.), author of Arithmetica and the most complex mathematician of Antiquity ${ }^{5}$.

Modern scientists and mathematicians have recently tried to identify the parts in these writings that correspond to Hypathia's original contribution, and out of an indepth analysis it has been concluded that both Theon and Hypatia have jointly produced the exegesis of mathematics of Antiquity based on authentic texts, unfortunately lost to us, therefore becoming co-editors of the works of great mathematicians including Ptolemy, Euclid and Diophantus. Additional to their contribution is the fact that the main purpose of such commentaries was to spread the knowledge amidst the pupils and to stimulate the scientific minds, thus conferring an experimental and educational meaning to Hypatia's work ${ }^{6}$.

Hypatia did not focus solely on the theoretical side of science, but also gave way to practical experiments. This we infer from the correspondence with one of her disciples, Synesius of Cyrene (in the Ep. De Dono Astrolabii and in the Ep. 15) which shows that scientific devices were used, such as the astrolabe, for astronomic measurements, or even the hydroscope, used for experiments in the area of physics. ${ }^{7}$ To corroborate this, the Suda also emphasizes the importance attributed to «other branches of philosophical knowledge» fostered by Hypatia, namely the philosophy of Plato and Aristoteles. Hypatia fits the profile that characterises the eclectic Philsopher of Antiquity.

It is not our intention to examine the identity of the real Hypatia and of the process of recovery from the violence inflicted upon her, or even reiterate her portrait as either a victim, heroine or martyr of Hellenism's scientific culture which still flourished within the environment of religious tumult of late Antiquity. Besides, the knowledge we have today about Hypatia has already some good reports, done by Michael Deakin in his work Hypatia of Alexandria: Mathematician and Martyr (2007) and by Maria Dzielska, who in 1995 published her work Hypatia of Alexandria, translated and published in Portugal by Relógio de Água in $2009^{8}$.

\footnotetext{
${ }^{5}$ Suda, the Byzantine dictionary from the 10th century A.D. (s.v. Hypatia 4, 644.1-646.5 Adler=166 Adler ed. on line (<http://www.stoa.org/solbin/search.pl?login=guest\&enlogin=guest\&db=REAL\&field=adlerhw_gr\&searchstr=upsilon,166>, from 2/12/2002) gathers information on several Greek writers: Socrates Scholasticus (4th-5th centuries A.D.), her contemporary and the author of Ecclesiastical History; Philostorgius from Cappadocia, her contemporary, also makes several remarks about her in his Arian Controversy, is also noted in the Ecclesiastical History. Hesychius of Miletus (5th century A.D.) , Onomatologus; from the last director of the Academy prior to its closure as ordered by the Roman Emperor Justinian, Damascius, the Life of Isidore (6th century A.D.), from John of Nikiu (7th century A.D.), Chronicle. Suda's main sources were Socrates Scholasticus, Hesychius of Miletus and above all Damascius.

${ }^{6}$ DEAKIN, 1994: 234-243. The «mathematical world of today owes Hypatia a great debt, for without her we would have much less of the works of Diophantus. If what survives for us is Hypatia's Commentary, then some of her work may appear here» (p. 239).

${ }^{7}$ Synesius of Cyrene (ed. Garzia, Les Belles Lettres) Ep. 16, in 413 A.D.: «I face such challenges at present that I am in need of a hydroscope. Try to create me one (...)».

${ }^{8}$ Adopting a method of rigorous investigation also shown towards the sources used in her work, Maria Dzielska hasn't escaped
} 
Western culture was sympathetic towards Hypatia. During the Age of Enlightenment it fell upon the English scholar Edward Gibbon (1798), through his well known work The history of the decline and fall of the Roman Empire ${ }^{9}$, the task of relating a narrative that would become the source of the most significant literary traditions and scientific propagation about Hypatia, being the tragic occurrence of her death by lynchment integrated in an episode of wider scope, entitled The death of Paganism (chapter. XLVII), one of Bishop Cyril's many displays of his assertion of power in the public arena of Alexandria.

and he soon prompted, or accepted, the sacrifice of a virgin, who professed the religion of the Greeks, and cultivated the friendship of Orestes. Hypatia, the daughter of Theon the mathematician, was initiated in her father's studies; her learned comments have elucidated the geometry of Apollonius and Diophantus, and she publicly taught, both at Athens and Alexandria, the philosophy of Plato and Aristotle. In the bloom of beauty, and in the maturity of wisdom, the modest maid refused her lovers and instructed her disciples; the persons most illustrious for their rank or merit were impatient to visit the female philosopher; and Cyril beheld, with a jealous eye, the gorgeous train of horses and slaves who crowded the door of her academy. A rumor was spread among the Christians, that the daughter of Theon was the only obstacle to the reconciliation of the praefect and the archbishop; and that obstacle was speedily removed. On a fatal day, in the holy season of Lent, Hypatia was torn from her chariot, stripped naked, dragged to the church, and inhumanly butchered by the hands of Peter the reader, and a troop of savage and merciless fanatics: her flesh was scraped from her bones with sharp oyster shells, and her quivering limbs were delivered to the flames. The just progress of inquiry and punishment was stopped by seasonable gifts; but the murder of Hypatia has imprinted an indelible stain on the character and religion of Cyril of Alexandria.

In light of the tragic circumstances surrounding Hypatia's death, let us examine the societal characteristics of Alexandria that may have precipitated the events leading to her murder on that fatal day in March 415 A.D., during the holy season of Lent.

The towns spreading over the Roman Empire during Late Antiquity, especially those located in the Middle East, Alexandria in particular, were prone to urban violence fuelled in many cases by religious conflict either between pagans and Christians or between rival powers adverse to Christianity. In fact, since 312 A.D. and more frequently from 390 A.D. onwards, religion became the reason used to justify the violence and clashes that often erupted.

the limitations intrinsic to the research on a figure like Hypatia: therefore most pages are dedicated to the telling of Hypatia's «literary tale» of which we have retained certain details in n. 1, and in the circumstances surrounding her death.

${ }^{9}$ Already available to the public (GIBBON, (1782) - History of the Decline and fall of Roman Empire. With notes by the Rev. H. H. Milman (1845), cap. XLVII, II. <http://www.gutenberg.org/files/25717/25717-h/files/734/734-h/gib4-47.htm\#2HCH$0001>$; references taken on 15/05/2011). 
The Tetrarchs, amongst them Theodosius I, were vigilant over such episodes of urban violence against which they passed laws aimed at keeping the religious unrest under control in the towns of Late Antiquity. Some of these reflected the implicit need to remove from the metropolis the conflictive elements, as a way to bringing relief to the economical and demographic burden caused by those citizens of scarce financial resources ${ }^{10}$. In order to resolve the issues related to safety and sustainability, though motivated by a more specific scope, laws were passed that limited the freedom of movement of specific groups linked to the Church: the Book 16 of the Codex Theodosiani, the section on religious issues, forbids monks from entering the cities, keeping them instead confined to the deserts and inhabited dwellings. Two years later, the dichotomy between a monastic life and a lay status, this associated the right to live in an urban environment, is further reinforced: those who break the law, as well as being punished, (iudiciariis aluntur iniuriis), are also forced to give up their monastic status, a condition upon which they are then allowed within the urban enclosures. Though of apparent contradiction, it must be noted that, once become laymen, ancient monks fell under general jurisdiction, not less repressive than the one that interdicted movements to particular human groups:

CTh., 16.3.1 Impp. Valentinianus, Theodosius et Arcadio (2nd September 390 A.D.)

Quicumque sub professione monachi repperiuntur, deserta loca et uastas solitudines sequi adque habitare iubeantur

CTh., 16.3.2 Impp. Valentinianus, Theodosius et Arcadio (17th April 392 A.D.)

Monachos quibus interdictae fuerunt ciuitates, dum iudiciariis aluntur iniuriis, in pristinum statum submota hac lege esse praecipimus; antiquata si quidem nostrae clementiae iussione liberos in oppidis largimur eis ingressus.

The following laws refer to a group of people known as the parabalaneis, who could have been directly associated with Hypatia's death, according to E. Gibbon. The sources we will refer to do not mention these laws as a consequence or a direct answer to the events of 415 in Alexandria, but they allow us to infer that the parabalaneis' presence was at least perceived as a menace to the security in the restless streets of Alexandria in the year of 415 A.D. The following year, in 416 A.D., Honorius and Theodosius received a complaint from the Alexandrian delegation, as the bishop could not freely move around the city, due to the wave of terror imposed by the parabalaneis. In response, the Roman Emperors issued a declaration, determining that clerici, or religious orders should be set apart from public affairs and from the curia. The parabalaneis must not exceed 500 in total, and must not be picked

\footnotetext{
${ }^{10}$ GREY, PARKIN, 2003: 284-299. Through this law, Theodosius aimed at keeping the poor and the destitute away from the cities, in order to make the necessary resources available to institutions of the Church so they can accommodate the invalid and the sick.
} 
amongst the rich or those who pay taxes ( hunc locum redimant). Instead they must proceed from the poor social strata of Alexandria (once again we notice their concern in «establishing control» over the poor by assigning them a role in the city). Their names must first be gathered and proposed to the urban prefect, who in turn will hand them to the Praetorian prefect. They are barred access to areas of leisure, the courts and government buildings, unless they have personal matters to resolve there, such as any pending court procedures, or in case they have been summoned by a third party or even if one of them has been appointed as an advocate for the group he represents. If anyone violates these rules, he must be expelled from the group, bear a punishment in accordance to the offense and never again be admitted amongst the parabalaneis ${ }^{11}$.

Two years later, in 418 A.D., the same Emperors decree an increase in the number of members of parabalaneis along with regulations about the attribution and selection processes: they must provide care for the sick, there must be six hundred of them instead of five hundred, specifically selected by the bishop (pro arbitrio uiri reuerentissimi Antistitis Alexandrinae urbis) for that role amongst the modest social classes (exceptis honoratis et curialibus). In case of death, a replacement must be appointed by the bishop. The law previously issued regarding access to areas of leisure and the courts remains unchanged ${ }^{12}$.

According to the information contained in the CTh 16.2.42.1, the parabalaneis are responsible for the «terror» instilled in the city. But the decisions of the Empereur reflect his intention to integrate the parabalaneis as a group in society, by defining the contours of their hierarchy, not to remove them from the city. A clear delineation is established between the clerici (i.e. those who have been ordained, being the Bishop the head of the hierarchy) and this brotherhood which must be submitted to the Praefectus Augustalis, a civic author-

\footnotetext{
${ }^{11}$ CTh.16.2.42.1 Quia inter cetera Alexandrinae legationis inutilia hoc etiam decretis scribtum est, ut reverentissimus episcopus de Alexandrina ciuitate aliquo non exiret, quod quidem terrore eorum, qui parabalani nuncupantur, legationi insertum est, placet nostrae clementiae, ut nihil commune clerici cum publicis actibus uel ad curiam pertinentibus habeant. Praeterea eos, qui parabalani vocantur non plus quam quingentos esse praecipimus, ita ut non divites et qui hunc locum redimant, sed pauperes a corporatis pro rata Alexandrini populi praebeantur, eorum nominibus viro spectabili praefecto Augustali videlicet intimatis et per eum ad vestram magnitudinem referendis. Quibus neque ad quodlibet publicum spectaculum neque ad curiae locum neque ad iudicium accedendi licentiam permittimus, nisi forte singuli ob causas proprias et necessitates iudices adierint, aliquem litem pulsantes uel ab alio ipsi pulsati uel in communi totius corporis causa syndico ordinato, sub ea definitione ut, si quis eorum haec uiolauerit, et breuibus parabalani eximatur et conpetenti supplicio subiugetur nec umquam ad eandem sollicitudinem reuertatur. (416 sept. 29).

${ }^{12}$ CTh.16.2.43 Idem aa. Monaxio praefecto praetorio. Parabalani, qui ad curanda debilium aegra corpora deputantur, quingentos esse ante praecepimus. Sed quia hos minus sufficere in praesenti cognovimus, pro quingentis sescentos constitui praecipimus, ita ut pro arbitrio viri reverentissimi antistitis Alexandrinae urbis de his, qui ante fuerant et qui pro consuetudine curandi gerunt experientiam, sescenti Parabalani ad huiusmodi sollicitudinem eligantur, exceptis videlicet honoratis et curialibus. Si qui autem ex his naturali sorte fuerit absumptus, alter in eius locum pro voluntate eiusdem sacerdotis exceptis honoratis et curialibus subrogetur; ita ut hi sescenti viri reverentissimi sacerdotis praeceptis ac dispositionibus obsecundent et sub eius cura consistant: reliquis, quae dudum latae legis forma complectitur super isdem Parabalanis vel de spectaculis vel de iudiciis ceterisque, sicut iam statutum est, custodiendis. Dat. III non. feb. Constantinopoli Honorio XII et Theodosio VIII aa. conss. (418 febr. 3). These dispositions were rewritten in CJ. 1. 3. 16; 1.3. 18.
} 
ity. The very fact that this aspect was mentioned shows that such ascendency, exclusively civic, was not established as so before 416 A.D.

They are selected amidst the poorest and those exempt of paying taxes. Two fundaments are on the basis of these exclusions: the members of these brotherhoods took upon their care the sick, the destitute and those left bereft in the city. This was a risky and repudiated task, one which constantly threatened their lives through the close contact with contagious diseases. However, those endowed with public offices, such as the ordained members of the Church (clergy and monks), benefited from forms of tax exemptions. Theodosius' law establishes that they must be recruited amidst the poorest, those who were already exempt from the payment of taxes, due to their economical fragility, absence of property or occupation to be taxed.

In this way, no one would be lured to this task simply to benefit from tax exemptions and, at the same time, the base of taxable contributions would not be decimated, a sensible matter in Egypt, where the brutality of state taxation was one of the reasons for common people to feel attracted to every kinds of political contest, even to indirect ones, like ecclesiastical power centered in bishop claims against Constantinople and the Emperor. The popularity of the task amongst the crowds of Alexandria was considerable, according to legislation. Since the access of the humble one on to grounds of public intervention was considerably limited, belonging to the parabalaneis could fulfill their necessity to participate and to intervene into public life.

The Emperor had an ambiguous task: to profit the opportunity to offer social integration to the poorest, (quieting trouble motivations, and to increase popularity by means of propaganda) but also to control them, reducing opportunities of erratic movements from them.

In our interpretation, the social reintegration of the parabalaneis offered the most humble citizens the possibility to climb up the social ladder, enabled through the association and service rendered to the powers above. In fact, the laws concerning these two social groups, triggered by Christianity, express the ambiguity of the political power, which on one hand tried to castrate the number and attributions of these groups (even through expulsions), and on the other uses them to carry out certain tasks in the city. Their dependency in relation to Egypt's governor after 416 A.D. shows that policing duties were also listed amongst them ${ }^{13}$.

13 The parabalaneis («the bathing servants») or in the Late Greek version, the parabolani, would have come into existence during the great plague of Alexandria, during the episcopate of Dionisius of Alexandria. Their name indicates their primary role: they were in charge of transporting the sickly to their treatments which comprised of cold or hot baths, depending on the illnesses. They were also tasked with removing the corpses from the streets. In their origins, therefore, they were not exactly nurses but merely litter carriers. I believe this is why they were later transferred to the role of police officers and bodyguards. One of their most valuable personal attributes was that of strength and physical stamina, whilst their therapeutic knowledge was of little importance. They consisted of a group of non-ordained Christians, of humble origin, devoted 
The Roman Emperors were aware of the problems inherent to social, political and religious cohesion in the cities located in the Eastern provinces of the empire and for that reason Constantine's long reign, succeed by his son Constans, even Julianus short-lived one, was characterized by a permanent strive to maintain an atmosphere of connivance and religious neutrality capable of assuring internal peace. Therefore, Theodosius has only decreed the state's religious adoption of Christianity after this had reached the vast majority of the empire including the elites and the urban masses, once it replaced the administrative structures which could no longer be sustained by a weakened state. In other words, in matters of law, the Roman Empire assumed a position de facto, one century after Christianity's progressive infiltration in society ${ }^{14}$. The parabalaneis, and their inclusion in the state, are a primary example of a compromise needed to preserve the public order. The survival of the Roman Empire depended not only upon an agreement being reached with the Church, of its capability to influence and secure the support of the urban population, but also upon its structures concerning security, social aid and education, which, to its own detriment, the state was unable to keep up with.

Being the religious motif the excuse found to justify the violence; this in turn translated the political, social and economical unrest bore by an empire in decline. Infuriated crowds were a contingency in the cities of the Late Roman Empire, populated by impoverished masses of people to whom the state had in the past guaranteed adequate means of subsistence thanks to a system of social benefits and free distributions of food supply. Towards the end of the 3rd century A.D. the means necessary to keep law and order were already waning. The free distribution of food had already stopped and the military resources needed in order to keep the law domestically were instead used to defend the external boundaries against foreign invasions.

In matters related to peace-keeping, Alexandria was a city of particular vulnerability. Owned by the Roman Prince, the province of Egypt was still the Empire's main producer of wheat since August's Principate in the 1st century A.D. This province was subjected to a hard fiscal regime imposed on its people, who mainly lived of agriculture ${ }^{15}$. For this reason, during the 4th century A.D., Alexandria witnessed numerous episodes of religious conflict and political rivalry fought between the two Episcopal headquarters of the Eastern Empire,

\footnotetext{
to work of social help and assistence to the sick and the burial of the dead. Their sense of obedience made them particularly suitable to fulfil the duties of bodyguards and special police forces. KAZHDAN, 1991: 1582. They were at the forefront of the riots of Alexandria which were responsible for Hypatia's death and equally of those which took place during the 2nd Council of Ephesus (The Latrocinium of Ephesus).

${ }^{14}$ BARNES, 1993: «Athanasius exercised power and protected his position in Alexandria by the systematic use of violence and intimidation».

${ }^{15}$ BAGNALL, 2003: 153-160. The rural population was taxed according to the size of the fields and wheat production. As it happened throughout the Empire, the sales of goods was taxed by the Chrysargyrion. The production of wheat in Egypt was vital in order to secure the level of grain stock of Constantinople, Rome and the army.
} 
Alexandria and Constantinople. The former has frequently boycotted the exports of cereals and the payment of taxes as means of political pressure forced on the emperors ${ }^{16}$.

It must be noted also the increasing association between national affairs and religious elites, of which bishops such as Athanasius, Theophile and Cyril are a good example for they were renowned for their theological arguments which became progressively intermingled with arguments of nationalistic interest. Being typically urban citizens of a Greek cultural background, their resistance against several movements of religious heterodoxy, sustained by the patriarchs in Constantinople or by its resident Emperor, was welcomed by the Christian communities of Egypt as an act of protest against the oppression levied upon them by Rome and its Eastern counterpart, Constantinople.

History itself explains the roots of this animosity. To the generic elements that define the economical and social history of the Late Roman Empire, we will add the specific factors that altogether turned Alexandria into a place particularly susceptible to urban violence ${ }^{17}$, in itself a symptom of a state struggling to assert its power and influence over a province with an increasing nationalistic ideology and progressively isolated from the Empire.

In first instance, since the Roman invasion and the inclusion of Egypt as a province of the Roman Empire, during Emperor Augustus' reign, Alexandria saw its political influence progressively weakened. At the beginning of the 4th century A.D., Emperor Constantine chose Bosphorus as the new capital of the empire. The cities of the Empire, including Rome, Nicomedia, Sirmio, Milan, Trier, Ravenna and Constantinople had been established as capitals in different or simultaneous moments of Late Roman world according to strategic and military criteria. Alexandria, however appeared to be protected from external invasions and for that reason it never enjoyed the capital status. Nevertheless, Egypt played such a vital role in the Roman economy that it was never granted any autonomy otherwise conceded to other provinces. Instead it was ruled with an iron fist by a governor who reported directly to the Emperor. The Egyptian farmers were forced to pay heavy taxes on their production, whose pricing and trading were also dictated and controlled by the Romans.

In second instance, we assist at the particular context of the birth of Christianity in

\footnotetext{
${ }^{16}$ HARDY, 1933: 188, 191. Sources, Sozomenos, H.E. Socrates, Life of Constantine «Athanasius, rich, powerful and capable of everything...». The reason of his exile was the fact that he boycotted the supply of cereals to Constantinople. Exiled at least five times by two emperors, Constantine and his son Constans, the first three times were due to treachery, not to heresy, ie, for disobedience to the political powers in a context of combat against the unorthodox militants and Arians.

${ }^{17}$ Socrates of Constantinople, HE 7, 13, (p. 160) describes the conflict between Christians and Jews straight after Orestes' arrival: «...About this same time it happened that the Jewish inhabitants were driven out of Alexandria by Cyril the bishop on the following account. The Alexandrian public is more delighted with tumult than any other people: and if at any time it should find a pretext, breaks forth into the most intolerable excesses...». In 7, 14, Socrates of Constantinople narrates the descent of five hundred monks from the deserts of Nitria and Alexandria to help in the attack of Orestes, the city praefect. The population however expels the monks and hand over their leader, Ammonius, to the authorities. Jailed and tortured to death, Bishop Cyril decrees that his body be placed in a church and proclaims him as a martyr in defense of the Christian faith.
} 
Alexandria, at the core of the Hellenistic world, and throughout Egypt as well. The arrival of Christianity in Egypt occurred very soon, profiting the geographical proximity with Palestine and its evangelization is traditionally associated with Jesus' apostle, Mathew. The Jewish communities of Alexandria's Diaspora, would have been amongst the first to embrace the new religion, as with many other important places of the Eastern Roman empire. The city of Alexandria, in the 2nd century A.D., however was a city of knowledge and libraries, which gathered conditions for the first systematic development of Christian theology. The first argumentation and philosophical elaboration of the Christian faith, under the influence of the Greek philosophy, more in particular of the Neoplatonic schools, took place in Alexandria. This city became not only the ground of doctrinal speculation and of the first biblical studies but also the stage of the first dogmatic controversies, born out of the attempt to merge the Hellenistic philosophy with the new religion. The theological school of Alexandria stands as the most ancient centre of sacred science in the history of Christianity, singled out by the interest applied to the investigation of the contents of the new faith and in the allegoric interpretation of the Scriptures, bridging Greek philosophy and Christian faith: Clemens, Origen, Dionysius of Alexandria and others from outside Alexandria, such as Gregory Thaumaturgius and Pamphile of Caesarea, who, having settled there, offered great contributions towards the development of the Alexandrian theology ${ }^{18}$.

Another interesting note is the fact that this Christian intellectuality, which was open minded towards speculation, preceded the establishment of the ecclesiastical hierarchy, still invisible at large and crippled by the systematic persecutions. Only in 200 A.D would Alexandria see the first monarchic bishop, Demetrius of Bactria.

In par with the Christian erudition, enlightened by Hellenistic philosophy, another characteristic of the Egyptian Christianity starts to emerge, consisting of its exposition to and capacity to resist to persecutions brought upon its believers. Numerous Christian communities of humble citizens were brutally persecuted in Egypt, particularly in the cities, by Roman Emperors such as Septimius Severus (end of 3rd century A.D.), Decius (middle of 3rd century A.D.), Galerius and Diocletian (beginning of 4th century A.D.).

In face of the demands imposed by the authorities, namely, the sacrifices and the swearing of an oath (libellum) of renunciation to Christianity, many have disbanded in fear. The problematic destiny of the traditores and the lapsi is at the source of the non-christological heresies prior to the council of Nicaea, such as the Novatianism and the Meletian Schism, all of African origin. What to do with the Christians who abnegated their faith in order to escape martyrdom? Should they be baptized again or have they definitely been severed from the Church? Others, such as Paul the Hermit, faced the religious persecution by treading on the habitual path of those Egyptians who resisted the fiscal or military authority by fleeing the civilized world of the cities and taking shelter instead in the inhospitable

\footnotetext{
${ }^{18}$ QUASTEN, Johannes (1960) - Patrologia I, p. 316 and following, II, p. 8 and following.
} 
deserts, in an act of anachoresis, which, from a methodological perspective, would in time lead to the flourishment of the monastic spirituality. Asceticism, as an impulse, has always been an integral part of Christianity from its very beginnings; however the historical phenomenon of the systematic movement of monasticism, as a pivotal force and element of continuous reinvention of the Church, was birthed in Egypt under the patronage of the Egyptians Saints Pachomius and Anthony.

Many however have faced the path of martyrdom. The Egyptian Church, through the impact caused by the implementation of a heroic character of the faith, elevated the aspect of martyrdom to a characteristic intrinsic to the nature of Egyptian Christianity ${ }^{19}$. The «Church of the Martyrs» was the designation given to it by Meletius, who having resisted the persecutions against Christianity, has ordained Arius and Isidorus amongst others as priests, when Peter of Alexandria fled his residence in 305-306 A.D. A futile act, since later on the Roman Emperor Maximinus would reinitiate the persecutions against Christianity in the Eastern side of the Roman Empire, and Peter ended suffering martyrdom in 311 A.D. ${ }^{20}$. These irregular ordinances, would pave the way for the grave schism of Arianism which, springing from Alexandria, fustigated the recent Peace of the Church, which appears to have been universal only during its probationary days.

It is not our purpose to conduct an in-depth analysis of the theological fundaments that characterized the Christian faith practiced in Alexandria, which in fact wasn't always of a heterodox nature: Arius was a native from Alexandria, but so were the so called «champions of orthodoxy», namely Athanasius, Theophile and Cyril.

Another special reference must be made to the fact that the Church of Alexandria was the initiator of an important current of theological controversy, in aspects related to the Holy Trinity and Christ, which stems above all from the degree of philosophical speculation associated to Christianity, whilst a religion, but also whilst school of thought (which has been inherited from the Hellenistic knowledge). It is but impossible to dissociate the theological controversy from the context of contestation and rivalry towards Constantinople, the new Rome of the East, having the respective patriarchs assumed opposing and hostile stances during the 4 th and 5 th centuries A.D. In such circumstances, any political agent or emissary sent by the Emperor was viewed as an aggressor, whilst bishops and the Church in general formed the headquarters of local resistance ${ }^{21}$.

\footnotetext{
${ }^{19}$ GRIGGS, 1990. Until 200 A.C., Egyptian Christianism remained undifferentiated whilst philosophical school until the arrival of Demetrius, the first bishop of Alexandria. There was a tension between the recently established hierarchy and the intellectuals (the catechetical school of Alexandria).

${ }^{20}$ The cult of relics and of the sacred locations of martyrdom whilst places of Christianity, in lieu of pagan religious places of cult (including temples, sanctuaries, tombs and idols). On the particularities of Egyptian Christianity (DIAS, 2010 XVIIXXIII; XXXI-XXXV).

${ }^{21}$ HALL, 1996. Egyptian Christianity became progressively isolated from catholic communion. In 451 A.D., at the Council of Chalcedon, the schism finally took place, upon decades of dogmatic discussion led by Constantinople and Alexandria. The
} 
We have left for the end of our analysis one of the characteristics of the Egyptian Christianity, which, in our opinion has been at the forefront of the dramatic events of 415 A.D.: its shattered sociological and ethnic composition. On one hand there was an impoverished Christian majority based in the countryside, which formed the social pool of influx into the monastic communities, where the Coptic language and culture were predominant; on the other hand, an educated minority based in the cities which formed an elite, half pagan half Christian, joined together by a common denominator, the Hellenistic philosophical tradition. For these knowledgeable elites the transition between a highly purified monotheistic paganism to Christianity was a relatively smooth process. In this manner, the interest towards science, erudition and speculation would be shared, and tertulias gathered pagans and Christians alike, according to ancient sources of information, as the friendship among Hypatia and Synesius was an example. However, for the first ones, Christian identity, (fixed in dogmatic formulas, firmly assumed against the much probation, martyrdoms and the violent acts practiced by an oppressing State) grew up blended with the defense of a national identity.

At this point we can naturally enquire why the Egyptian nationalism, once awakened in the minds of the people, was inspired by a new foreign religion and not by the traditional gods of the Egyptian pantheon.

First of all, it must be considered that the traditional Egyptian religion was in rapid decline, due to the systematic attempts to its disfigurement through a process of fusion with Hellenism. The places that were sacred to the Egyptian religion, including temples and tombs, had been ruined by abandon and successive robberies that took place much prior to the systematic attacks set by the Christians against the monuments that formed Egypt's heritage of its religious traditions. There were, however, certain common elements between the traditional Egyptian religion and Christianity: in the former as in the latter the priestly orders were given managerial and leadership duties concerning access to the religious mysteries; the belief in life after death, depending upon one's earthly existence, was equally present in both forms of religions ${ }^{22}$.

Let us now analyze the confluence between these factors and the events surrounding Hypatia which led eventually to her death: we strongly believe that the conflict of 415 A.D. had political and ethnic contours, that is, Hypatia's death was the byproduct of a set of cir-

monophysite Christianity conquered its place in the Church of Alexandria. Since then, the calendar of the «Days of the Martyrs», previously established in 303 A.D. (date that marks the beginning of the Christian persecutions by Diocletian), has to this day become the official calendar of the Coptic Church.

22 BAGNALL, 2003: 261-268. The author points at which show that between the 2nd and 3rd centuries A.D., Egypt's traditional religion, along with its temples and priestly orders, reached a point of crisis (p. 268) «the consequences for Egyptian society of the starvation and death of the temples were more far-reaching [...] It may be that this vacuum helped make the spread of Christianity in Egypt so explosive in fourth century: it replaced that lost structure of life». 
cumstances beyond her control and whose cause is deeply steeped in the history that forged the relations between the Greek, Jewish and Roman elements with the Egyptian one ${ }^{23}$.

So that our explanation becomes more plausible, let us first point at a secondary observation: hoi hellenes is the name that is assigned in the biblical texts, originally written in Greek, to non-Jews (e.g. Maccabeus) and those who are not followers of Christ (The Gospels, The Epistles of Paul). The terms of ho laos and ta ethne can also be found there referring to «people susceptible of being converted». Hoi hellenes is the term that will be adopted during the first literary clash between Christians and non-Christians, with the first written Christian polemic literature. Even Athanasius, despite his Hellenistic education and cultural background, rebukes the science and the philosophy of the Greeks (i.e., of the pagans) in favor of the simplicity of the faith of the Egyptian monks, of whose sanctity he becomes a spokesman ${ }^{24}$.

However, in the Latin translations of the respective texts, the same term hoi hellenes appears primarily translated in its Latin counterpart as gentiles (meaning the people, the pagans) and secondarily as paganus ${ }^{25}$. We can infer from this data that the designations of the people in question point towards a content not directly associated with religion. The Latin words imply a sociological and geographical differentiation from the other, but not an ethnic one. The term paganus, which has become generalized and which figures in modern languages, refers originally to the inhabitant of the pagus, of the countryside, later converted by the incoming Christians from the cities. Already the Greek term hellenes, used by Greek-speaking followers of a persecuted religion, when referring to non-Christians, in particular by those hostile to Christianity (as used by the Maccabeus when referring to the Seleucids who opposed Judaism) is a term of ethnic designation. These hellenes, in Egypt, even amongst the Greek-speakers, form the cultural and economical elite, who are close to the political powers, the descendents of the «Greek invaders» who would change the Egyptian culture forever and who would open the door to the Roman domain. This class of citizens, to whom Hypatia and Synesius belonged, was impenetrable to the vigorous and demographically superior movement of the humble ones ${ }^{26}$. This hypothesis helps us to bet-

\footnotetext{
${ }^{23}$ For obvious reasons, the imperial legislation recorded the events occurred in 415 A.D. as a period of «terror» triggered by the parabalanei but does not make any references to the victims of that terror. This is an issue related to public order which affects the whole city in general.

${ }^{24}$ Athanasius of Alexandria, Lógoj kata\ (Ellh/nwn. S. Jerónimo, in De Viris Illustribus, 87, translates by Oratio Contra Gentes. The Novellae of Justinian integrated in the Corpus Iuris Civilis, already written in Greek, also make use of the term hellenes to designate the non-Christians. The Latin translation of this compilation uses the term pagani. Theodosius' decrees included in the CJ against paganism, also use the term hellenes (JOHNSTON, 1999).

${ }^{25}$ Rom 2,12; Act. 19, 17.

${ }^{26}$ We mention, as an example of the existing gap between the distinctive economical and social orders even if all Christian: The Bishop Synesius of Cyrene, one of Hypatia's disciple and friend, once describes to her, in a letter, the people with whom he shares a journey by boat which near toppled (Ep. 5) «... half of the passengers were Jews, that race excluded from the Alliance, convinced that the killing of Greeks was an act of piety eusebein). (...) The remainder, plain country people who
} 
ter understand the tense social context in which Hypatia found herself and whose contours are also specific of the Greek-Roman Egypt.

There is a common denominator in the various narratives pertaining to Hypatia's death. Each of the different versions reflects mainly each author's personal interpretation of the events, and none of those divergences offers proof of validation in of a particular version of the events. We will mention but a few.

The most remote sources can be found in the Ecclesiastical History by Socrates Scholasticus (379-450), himself a contemporary of Hypatia, being a Christian as well as a lawyer living in Constantinople. Hypatia emerges as an episode of the opposition between Cyril and Orestes. She is presented as a distinguished figure of vast knowledge, who dedicated herself to teaching others Plato's and Plotinus' principles of philosophy. Her notable character and the proficiency of her teachings quickly turned her into a public figure, regularly mixing with the magistrates, whose company she did not feel abashed to display in public. Her reputation begins to arouse jealousy and a rumor starts to spread that she is the cause of the conflict between Orestes and Cyril. The account is brief and probably authentic as it relies on contemporary witnesses of the events. The attackers are a Christian mob, instigated by an excessive zeal, under the leadership of Peter, the Reader. A modern analysis of this episode shows that each of its contours is an expression of pettiness: she is the perfect escape goat in a society in tension - a woman of high social status, non-Christian, knowledgeable, who uses the public arena to teach and make her voice heard, away from the characteristics that traditionally define the feminine gender ${ }^{27}$. The parabanale $i$ are not mentioned, but it is established the correlation between Hypatia's lynchment and the disturbances arisen in Alexandria on the account of the rivalry between Cyril and Orestes.

had never seen the sea ( a)gelai=oi gewrgoi $\backslash$ ) (...). They all seemed to have physical deformations in parts or across their whole bodies and they addressed mutually as «cripple», «hernia»; «one-armed» ou «cockeyed». (...) such scene made us laugh (...)».

${ }^{27}$ Socrates Scholasticus H. E. 7. 15. (PG 67, 29-872, Col 761); «There was a woman at Alexandria named Hypatia, daughter of the philosopher Theon, who made such attainments in literature and science, as to far surpass all the philosophers of her own time. Having succeeded to the school of Plato and Plotinus, she explained the principles of philosophy to her auditors, many of whom came from a distance to receive her instructions. On account of the self-possession and ease of manner, which she had acquired in consequence of the cultivation of her mind, she not infrequently appeared in public in presence of the magistrates. Neither did she feel abashed in coming to an assembly of men. For all men on account of her extraordinary dignity and virtue admired her the more. Yet even se fell a victim to the political jealousy ( (o fqo/noj) which at that time prevailed. For as she had frequent interviews with Orestes, it was calumniously reported among the Christian populace, that it was she who prevented Orestes from being reconciled to the bishop. Some of them therefore, hurried away by a fierce and bigoted zeal, whose ringleader was a reader named Peter, waylaid her returning home, and dragging her from her carriage, they took her to the church called Cosareum, where they completely stripped her, and then murdered her with tiles. After tearing her body in pieces, they took her mangled limbs to a place called Cinaron, and there burnt them. This affair brought not the least opprobrium, ( o) u mi/kron mw=mon ), not only upon Cyril, but also upon the whole Alexandrian church. And surely nothing can be farther from the spirit of Christianity than the allowance of massacres, fights, and transactions of that sort. This happened in the month of March during Lent, in the fourth year of Cyril's episcopate, under the tenth consulate of Honorius, and the sixth of Theodosius. Also Sozomenus, H. E. PG 67 844-1630; Teodoret of Cyr, H. E. PG 882-1280. 
Damascius, one of the last standing academics in Athens, who retired into exile in Persia after Emperor Justinian ordered the closure of the Academy, and the author of The Life of Isidorus, was the first one to formulate Cyril's direct responsibility in this episode ${ }^{28}$. It is believed that the historical reference to Hypatia in the Suda is a reconstruction based on fragments from his work. This is the main source of the events in the memory of future generations. In that testimony, jealousy is again mentioned as the cause for the ensuing events, the only difference consisting in a more romanticized narrative: Cyril, in passing by, noticed the throng of men coming in and out of Hypatia's house and, consumed by jealousy, starts conjuring up the attack whose execution he entrusts to a group of thugs. No mention is made here to any conflict of a religious nature, but the sociological conflict becomes apparent. Hypatia was admired by everyone and the city rulers, i.e. the elites, frequently attended her classes in philosophy «The rest of the city loved and honored her exceptionally, and those who were appointed at each time as rulers of the city at first attended her lectures, as also it used to happen in Athens».

Philostorgius of Cappadocia, born in 368 A.D., was also the author of the Ecclesiastical History which survived only through an epitome written by Photius, a Byzantine patriarch. He was a follower of Anomousianism, a divergent branch of Arianism, (the Nicene creed was homoousian). As expected, the account it gives of the events portrays Hypatia as a victim caught in the conflict between Christian orthodoxy and arianism ${ }^{29}$.

The Chronicle written by John of Nikiu is the most recent of the surviving accounts and it corroborates the concept that History belongs more to those who narrate it than to those who play a role in it. John of Nikiu is an author from the Lower Egypt, who lived in the 7th century A.D., and his work survived thanks to an Ethiopian version copied from an Arabic text.

Although there may be some ambiguous traits in Hypatia's character, implicitly mentioned in the previous texts, (a deviation from the traditional feminine archetype of those days; the close association with the elites; the continuous circle of admirers around her) John of Nikiu is the only to show a negative image of Hypatia, as the agent in a conflict of religious and moral demeanor. Here she is described as a pagan philosopher, engaged in practices of black magic, divination, astrology and music. During the unfolding of the con-

\footnotetext{
${ }^{28}$ Suda, s.v. Hypatia, 4.645.4-16. Ed. de Adler, Dam. Frag. 102, p. 79.18 a 81.10 Zintzen. (ATHANASSIADI, 1999: 403). Suda, s.v. Hypatia, 4.645.4-16. «She suffered this because of envy and her exceptional wisdom, especially in regard to astronomy. According to some, [this was the fault of] Cyril,[5] but according to others, [it resulted] from the inveterate insolence and rebelliousness of the Alexandrians. For they did this also to many of their own bishops - consider George and Proterios. Concerning Hypatia the philosopher, proof that the Alexandrians [were] rebellious».

${ }^{29}$ Philostorgius HE VIII.9. (PG The Ecclesiastical History of Philostorgius is a story of the Arian controversy, which appears mentioned in the writings of Photius (856-887) Philostorgius, in Photius, Epitome of the Ecclesiastical History of Philostorgius, 9, 9: «Philostorgius says, that Hypatia, the daughter of Theon, was so well educated in mathematics by her father, that she far surpassed her teacher, and especially in astronomy, and taught many others the mathematical sciences. The impious writer asserts that, during the reign of Theodosius the younger, she was torn in pieces by the Homoousian party.
} 
flicts between Jews and Christians, between Orestes and the Episcopate, between the monks in the cities and the surviving pagan sites, she is accused of alienating the Governor from the Church through magical spells. The city rejoices at the annihilation of Hypatia, the last standing pillar of idolatry. Peter, who led the attack is hailed as a «a true believer in Christ» and Cyril is acclaimed as undisputable leader ${ }^{30}$. In this way, the death of Hypatia contributes to reinforce the Bishop's power and to unite ecclesiastical and political purposes.

We reserved for the conclusion some aspects to consider on the account of the different narratives about Hypatia: first of all, the sources omit the direct action of the parabalanei, who do not even appear mentioned in the texts. The responsibility seems to dilute itself in the crowds, cheering at the recent events of violence and in particular at the execution of Ammonius, the Nitrian monk, for previously stoning the Roman Praefect Orestes. Peter the Reader (that is, not a parabalanus, but someone invested of a religious ministry of a lower rank under the dependence of a Bishop) points at a target, the one responsible for the acrimonious relations between Cyril and Orestes. Ironically, Hypatia is sacrificed because the population wants to put an end to the distrust between two post-holders of the religious and political powers.

The level of influence that each one of these powers exerts already appeared imbalanced: it is Cyril who enjoys the ascension to power, as the Bishop acclaimed by the population of Alexandria, following the death of his predecessor Theophile. In contrast, there is a Roman Prefect, who receives from the Emperor the responsibility of ruling a complex city. Orestes, as someone perceived as a member of a elite disconnected from the people, has a lot to prove, that he is deserving of the confidence of the people, that he is a baptized Christian, whose public office does not pose any threat to the Christian supremacy, under the pretext of a tolerance and an impartiality, which the State could no longer afford as an excuse. In the end, if the mob was given a choice, it would have been Orestes who they would have lynched, if it wasn't for the fear of the consequences faced for the death of one of the Emperor's officials.

\footnotetext{
${ }^{30}$ CHARLES, 1916: 87-103: «And in those days there appeared in Alexandria a female philosopher, a pagan named Hypatia, and she was devoted at all times to magic, astrolabes and instruments of music, and she beguiled many people through (her) Satanic wiles. 88. And the governor of the city honoured her exceedingly; for she had beguiled him through her magic. And he ceased attending church as had been his custom. But he went once under circumstances of danger. And he not only did this, but he drew many believers to her, and he himself received the unbelievers at his house. [...] . And thereafter a multitude of believers in God arose under the guidance of Peter the magistrate -now this Peter was a perfect believer in all respects in Jesus Christ - and they proceeded to seek for the pagan woman who had beguiled the people of the city and the prefect through her enchantments. 101. And when they learnt the place where she was, they proceeded to her and found her seated on a (lofty) chair; and having made her descend they dragged her along till they brought her to the great church, named Caesarion. Now this was in the days of the fast. 102. And they tore off her clothing and dragged her [till they brought her] through the streets of the city till she died. And they carried her to a place named Cinaron, and they burned her body with fire. 103 . And all the people surrounded the patriarch Cyril and named him «the new Theophilus»; for he had destroyed the last remains of idolatry in the city».
} 
A special reference must also be made to the way in which Hypatia dies, lynched by a furious mob, exposing the philosopher to public humiliation. The fanatical crowd who overthrows her from her chariot or her chair, that tears her clothes apart, mutilates her body with oyster shells, drags her along the streets and finally sets her disfigured body on fire, this is the same crowd who, over the years, has profanated the pagan temples, knocked down sacred effigies, set shrines on fire, trying through that violence to exterminate any visible signs of religions and cultures rival to the Christianity, the only recognized as the legal religion of the State. The various accounts of the way in which Hypatia is tortured to death, all converging to the same details, lead us to think that even in death did Hypatia become a symbol, along the wrecked temples, of the fanaticism and iconoclastic intolerance that thrived in the Eastern Roman empire of Late Antiquity. 